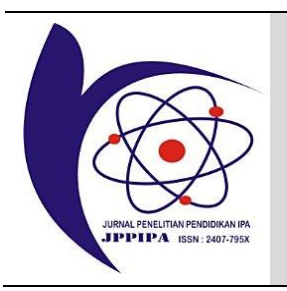

\title{
The Differences of Analytical Thinking Skills on Biodiversity Material in Guided Inquiry Model with Conventional Class
}

\author{
Rama Cahyati ${ }^{*}$, Bambang Subali² \\ ${ }^{1}$ Department of Biology Education, Postgraduate, Universitas Negeri Yogyakarta, Yogyakarta, Indonesia
}

DOI: $\underline{\text { 10.29303/ippipa.v8i1.1076 }}$

\section{Article Info}

Received: October 31, 2021

Revised: December 22, 2021

Accepted: December 23, 2021

Published: January 31, 2022

\begin{abstract}
This study aims to compare whether there are differences in analytical thinking skills between classes that use guided inquiry models and conventional classes that use discussion methods and to find out whether guided inquiry models can improve analytical thinking skills in class X SMA. This type of the research is a quasi experimental research that uses a pretest posttest control group design. The population of this research were students of class X SMA Negeri 1 Kalasan and class X SMA Negeri 1 Prambanan. The sample in this research were 4 classes with a total of 104 students. Sampling in this research was conducted by cluster random sampling. The results of the $t$ test obtained the value of sig. (2-tailed) of 0.000 , the probability value is less than 0.05 , which means that there are differences in analytical thinking skills in the guided inquiry class and the conventional class. The gain score test results obtained a value of 0.71 with a high category, meaning that the use of the guided inquiry model can improve analytical thinking skills in class X SMA.
\end{abstract}

Keywords: Guided Inquiry; Analytical Thinking Skills; Biodiversity

Citation: Cahyati, R., \& Subali, B. (2022). The Differences of Analytical Thinking Skills on Biodiversity Material in Guided Inquiry Model with Conventional Class. Jurnal Penelitian Pendidikan IPA, 8(1), 32-38. https:// doi.org/10.29303/jppipa.v8i1.1076

\section{Introduction}

Indonesia's involvement in Trends in Mathematics and Science Study (TIMSS) aims to determine cognitive abilities and scientific literacy. Aspects of analytical thinking skills that are included in the cognitive abilities that are applied in TIMSS can be used to show the profile of students thinking abilities (Rofiah, 2013). The aspect of analytical thinking skills is one aspect that is highlighted in the learning process which is expected to make students have knowledge and skills (Spaska, 2021). This seems to have not materialized because the learning process in the classroom still emphasizes on the results of knowledge only, this results in students not having the skills to be used as provisions if they are in the community. So the need for a curriculum to lead to improvement.

The direction of improvement has been carried out by implementing the 2013 curriculum. The 2013 curriculum which is based on character and competence, among others, wants to change the pattern of education from an orientation towards educational outcomes and materials as a process through an integrative thematic approach (Ikhsan, 2018). The implementation of the competency based 2013 curriculum as well as character based is expected to be able to improve the quality of educational processes, and outcomes that lead to the formation of character and noble character of students as a whole (Arjani, 2020). Good education is an effort that succeeds in bringing students to the goal to be achieved, namely so that the material conveyed is fully understood by students (Murizal, 2012).

With different interpretations of curriculum terms, attitudes, and values towards various pedagogical approaches can affect how students learn in school (Tse, 2013). The 2013 curriculum is a reference and guide for educational institutions in planning, 
preparing, and implementing their programs (Mulyasa, 2017). In the 2013 curriculum, the learning process carried out by the teacher has used a scientific approach. Scientific is a learning process that activates students in understanding concepts (Mustika, 2016). All subjects are taught with a scientific approach, through observation, asking, trying, thinking, associating, and communicating which aims to see whether students have really mastered thinking ability from the lowest level to higher order thinking ability. In this study, higher order thinking ability are limited to analytical thinking skills.

Analytical thinking skills is the ability to understand problem situations by looking at them as a whole including the ability to identify fundamental problems in complex situations (Kurniati, 2016). According to (Anderson \& Krathwohl, 2010) analytical ability include learning to determine relevant or important pieces of information (differentiating), determining ways to organize these pieces of information (organizing), and determining the purpose behind the information (attributing). Analyzing ability are abilities that are generally possessed by scientists (Cahyono, 2017). Analyzing concepts is very important in science, especially biology, therefore students need to be given the opportunity to analyze the concepts they already have.

Based on previous research, the results of the analysis of the level of analytical thinking skills of class IX-E SMP Ma'arif 1 Ponorogo are still in the low category, as evidenced by the results of the average overall analytical thinking skills indicator obtained which is 5.30 which is still less than the Minimum Completion Criteria $(<75)$ determined by the school (Fitriani, 2021). The results of other studies show that the level of students analytical ability on the three differentiating indicators has a value of 16.6, organizing is 46.6 , and attributing is 7.2 , so it can be concluded that students analytical ability are at a low level (Winarti, 2015). The results of research from (Astriani, 2017) show that students analytical ability on indicators differentiating 3.01 (good), organize 2.93 (good), and connect 2.47 (not good). The link indicator needs more attention. The results of previous studies showed that the level of analytical thinking skills and evaluation of class X IPA SMA X Jakarta in the high group was $13.3 \%$, the medium group was $26.7 \%$, and the low group was $60 \%$ (Nilah, 2020).

One of the factors that influence students low analytical thinking skills is habits in everyday life (Heong, 2011). Students have difficulty in achieving learning concepts as expected, such as some students are able to solve problems, but do not understand what is contained in the questions and many students are not able to make a conclusion from the material that has been studied (Sulistiawati, 2014). There are two factors that can affect students low analytical thinking skills, including internal factors that can be influenced by parental genetic factors. External factors are from the environmental conditions in which they live including social, cultural, economic, and educational facilities where they study (Nugraha, 2017).

There are also several things that can cause students to be less able to analyze concepts, namely because students do not understand the material being taught, because students only memorize without understanding the material. The lack of students ability in analytical thinking is because students are less able to analyze the statements shown by not being able to give true and complete reasons so that the ability to make conclusions is still low and not used to it. According to Effendi (2017) students can be said to understand the material when students are able to construct meaning from instructional messages including oral, written, and graphic communication from the material presented. According to (Utari, 2012) by understanding the material students can develop their abilities in learning, students can analyze the concepts they have learned to solve simple to complex problems.

The analytical thinking skills of each student is different from each other, depending on how ready students are in receiving material, processing, and absorbing subject matter (Fadly, 2021). Lack of analytical thinking skills can be caused by students who are cool to play alone, students who are less active during the learning process, and learning models that are monotonous and less attractive to students. The standard of analytical ability that is lacking will result in learning outcomes that are far from the learning objectives (Johnson, 2014). Improvement of analytical thinking skills can be done by applying an active learning model centered on students (Rosana, 2014). From the description above, the researchers conducted research using a student oriented learning model and actively involved students in learning, namely the guided inquiry model.

Guided inquiry model is a learning model that allows students to move step by step from identifying problems, defining hypotheses, formulating problems, collecting data, verifying results, and generalizing conclusions (Mattew, 2013). Thus, the guided inquiry model is expected to be able to improve students analytical thinking skills. Seeing the importance of the role of analytical thinking skills in an effort to improve student learning outcomes and facing advances in information technology as it is today, it is necessary to conduct research with the aim of knowing whether the guided inquiry model can improve students analytical thinking skills from student learning outcomes data by 
using a description test that includes indicators of analytical thinking skills.

\section{Method}

This research when viewed from the field of education is a quasi experimental research. The research design used was pretest posttest control group design. The research population, namely students of class X SMA Negeri 1 Kalasan and class X SMA Negeri 1 Prambanan. The sample in this study were 4 classes with a total of 104 students. Sampling in this research was carried out by cluster random sampling from class $X$, each consisting of 4 classes, both at SMA Negeri 1 Kalasan and SMA Negeri 1 Prambanan. The data analysis technique in this study was using the independent sample t-test. The stipulation is that if $\mathrm{P}$ (sig) $>0.05$, the data concerned is declared homogeneous, meaning that there is no difference between the conventional class and the guided inquiry class. On the other hand, if $\mathrm{P}(\mathrm{sig})<0.05$, the data in question is declared not homogeneous, meaning that there is a difference between the conventional class and the guided inquiry class (Nurgiyantoro, 2015).

To find out the increase in students analytical thinking skills, a normalized gain score was calculated. The normalized gain score formula is:

$$
\mathrm{g}=\frac{\text { posttest score-pretest score }}{\text { maximum score-pretest score }} .
$$

The average value $(\mathrm{g})$ is used to determine the increase in analytical thinking skills with the guided inquiry model. Based on the category of normalized gain score according to Hake (1999) it is presented in table 2.

Table 1. Normalized gain score category

\begin{tabular}{ll}
\hline Normalized Gain Score & Category \\
\hline $\mathrm{g}>0.70$ & High \\
$0.30 \leq \mathrm{g} \leq 0.70$ & Medium \\
$\mathrm{g}<0.30$ & Low \\
\hline
\end{tabular}

\section{Result and Discussion}

The data in this study were obtained at SMA Negeri 1 Kalasan and SMA Negeri 1 Prambanan. At the beginning of learning in each class, namely the conventional class and the guided inquiry class, a pretest was given to describe the level of analytical thinking to determine the initial abilities of the two classes. Then at the end of the lesson, each class, namely the conventional class and the guided inquiry class, was given a posttest about the description of the level of analytical thinking. The learning process in the guided inquiry class uses the guided inquiry model, while the conventional class uses the discussion method. Based on the data analysis of the students initial analytical thinking skills in working on the description questions, the achievement data obtained as shown in table 2 below.

Table 2. Analytical thinking skills pretest result in conventional class and guided inquiry class

\begin{tabular}{lll}
\hline \multirow{2}{*}{ Type } & \multicolumn{2}{c}{ Analytical Thinking Skills } \\
\cline { 2 - 3 } & Conventional Class & $\begin{array}{l}\text { Guided Inquiry } \\
\text { Class }\end{array}$ \\
\hline Mean & 65 & 66.50 \\
Maximum & 80 & 81.57 \\
Minimum & 43.53 & 48.53 \\
SD & 9.31 & 6.98 \\
\hline
\end{tabular}

Based on the data from the initial analytical thinking skills, the conventional class obtained an average score of 65 while the guided inquiry class obtained an average score of 66.50 . This shows that the conventional class and the guided inquiry class have almost the same initial ability with a difference of 1.50 . The maximum and minimum scores in the conventional class and the guided inquiry class show almost the same value. This supports that the conventional class and the guided inquiry class have the same analytical thinking skills. The standard deviation in the conventional class is 9.31 and the guided inquiry class is 6.98. The difference in scores between the conventional class and the guided inquiry class is not much different, it shows that the data between the conventional class and the guided inquiry class has almost the same data variability.

Table 3. Analytical thinking skills posttest result in conventional class and guided inquiry class

\begin{tabular}{lll}
\hline \multirow{2}{*}{ Type } & \multicolumn{2}{l}{ Analytical Thinking Skills } \\
\cline { 2 - 3 } & Conventional Class & $\begin{array}{l}\text { Guided Inquiry } \\
\text { Class }\end{array}$ \\
\hline Mean & 75.50 & 86 \\
Maximum & 92 & 95 \\
Minimum & 50 & 68 \\
SD & 8.94 & 5.47 \\
\hline
\end{tabular}

The results of analytical thinking skills based on the posttest value of the conventional class obtained an average value of 75.50 while the guided inquiry class obtained an average value of 86 . The difference in value between the guided inquiry class and the conventional class was 10.50 . So it can be concluded that between the guided inquiry class and the conventional class there is a large difference in analytical thinking skills after receiving different treatment. The maximum and minimum values in the conventional class and guided inquiry class show different values. So that it can be used to support the 
statement that the value of analytical thinking skills is different. The standard deviation between the conventional class and the guided inquiry class showed close results, namely 8.94 and 5.47 . This shows that the conventional class and the guided inquiry class have almost the same data variability.

The results showed that the analytical thinking skills before the learning process took place in the conventional class and the guided inquiry class on the pretest were the same. After learning with the guided inquiry model was given to the guided inquiry class and after the discussion method was given to the conventional class, the results of the analytical thinking skills in the guided inquiry class were higher than the analytical thinking skills in the conventional class. This can be seen from the graph of the value of analytical thinking skills below.

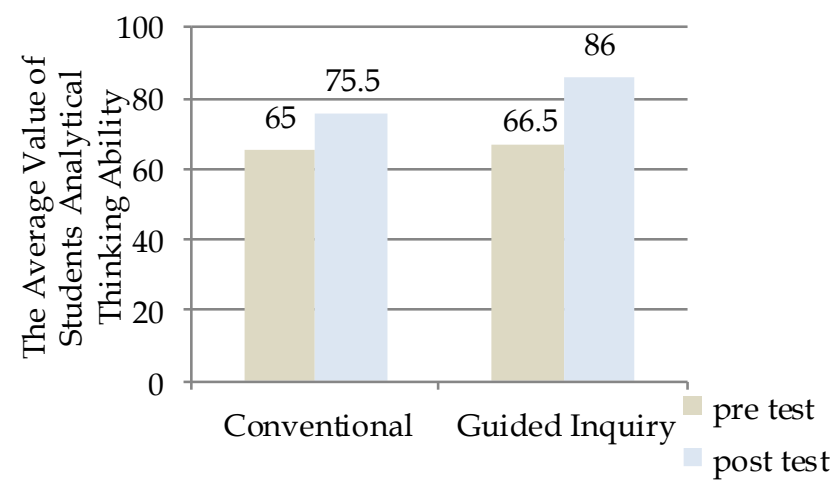

Figure 1. The Average Value of Students Analytical Thinking Skills in Conventional Class and Guided Inquiry Class

Table 4. Mode comparison of conventional class and guided inquiry model

\begin{tabular}{lll}
\hline \multirow{2}{*}{ Value Interval } & $\begin{array}{l}\text { Conventional } \\
\text { Class }\end{array}$ & $\begin{array}{l}\text { Guided Inquiry } \\
\text { Class }\end{array}$ \\
\hline$>90$ & 1 & 20 \\
$>80-90$ & 18 & 28 \\
$>70-80$ & 24 & 5 \\
$<70$ & 11 & 1 \\
\hline
\end{tabular}

The difference in analytical thinking skills can be seen from the scores that appear the most, for the conventional class there is an interval of values $>70-80$ with a total of 24 students, while in the guided inquiry class there is an interval of values $>80-90$ with a total of 28 students. Thus, there are differences in analytical thinking skills between conventional classes that use the discussion method and guided inquiry classes that use guided inquiry models. The difference in the results between the conventional class and the guided inquiry class based on the mean value was significantly different.
Table 5. The result of independent sample t-test on pretest and posttest

\begin{tabular}{lll}
\hline Data & Sig. (2-tailed) & Description \\
\hline Pretest & 0.235 & Not significant \\
Posttest & 0.000 & Significant \\
\hline
\end{tabular}

The analytical thinking skills of the conventional class and the guided inquiry class showed different results, also evidenced by the independent sample $t$ test. The results of the independent sample t-test on the pretest data obtained a sig value (2-tailed) of 0.235 . The probability value is greater than 0.05 so it can be concluded that there is no difference in the pretest scores in the conventional class and the guided inquiry class. The results of the posttest scores were tested with the independent sample t-test, which showed that the value had a sig. (2-tailed) of 0.000 . The probability value is less than 0.05 so that the value is very significant and it can be concluded that there are differences in the posttest scores in the conventional class and the guided inquiry class, meaning that the use of the guided inquiry model can improve analytical thinking skills on biodiversity material in class X SMA. From the results of the independent sample t-test on the posttest data, it shows that learning through the guided inquiry model has a positive effect and can improve analytical thinking skills. This is in line with research (Annisa, 2016) which shows that through the application of guided inquiry learning models can increase analytical thinking skills by $28.68 \%$.

Table 6. Gain score result

\begin{tabular}{lll}
\hline Class & Gain Score & Category \\
\hline Conventional & 0.30 & Medium \\
Guided Inquiry & 0.71 & High \\
\hline
\end{tabular}

The pretest value in the conventional class is 65 and the posttest value is 75.5 . An increase of 10.5 was obtained with a gain score of 0.30 so that it was included in the medium category. Meanwhile, in the guided inquiry class, the pretest score was 66.5 and the posttest value was 86 , so there was an increase of 19.5 with a gain score of 0.71 in the high category. So it can be concluded that the learning process with the guided inquiry model can improve analytical thinking skills with a high category. This is in line with the results of (Sukma, 2016) which shows that there is a significant influence of the guided inquiry learning model on the learning outcomes of class X students of SMA Negeri 11 Samarinda.

Analytical thinking skills between conventional classes and guided inquiry classes can be different because in the learning process using the guided inquiry model, learning refers to investigation activities and explains the relationship between objects and 
events (Sukriyanto, 2014). This method involves students in mental processes to find a concept based on the information provided by the teacher. According to (Patandean, 2014) the guided inquiry model is more oriented towards student centered classroom activities and allows students to learn using various learning resources. Thus, students will be trained to relate and analyze the concepts they have acquired during learning and can relate them to events in their daily lives that they experience.

In the literature analytical thinking skills is defined as an integrated ability that combines elements such as searching, selecting, and categorizing relevant data and information (Yulina, 2019). According to (Maryani, 2016) analytical thinking skills are an active process and an orderly way of thinking to understand information in depth. Analytical thinking skills is the ability to analyze a problem by linking some information so that it can solve a problem (Yuwono, 2020). Analyzing skills are an important part of problem solving so that students can make the right decisions (Desti, 2020). By using these skills, students are encouraged to find the truth of the information obtained.

The learning process in the classroom should use cognitive competence at the analytical level, not just the level of understanding (Dettmer, 2006). In the learning process, teachers must design learning tools and apply learning strategies that allow teachers to involve and guide students in applying their knowledge (Agustina, 2016). This is very important because according to Yustyan (2015) the selection of learning strategies is one factor that is quite influential in success in learning. Teachers must manage learning with an emphasis on analytical thinking.

Improved analytical thinking skills can be done by applying the right learning model. Thus the guided inquiry model can be used as an alternative that can be used to improve students analytical thinking skills. Guided inquiry model is a learning model that refers to investigation activities and explains the relationship between objects and events (Ural, 2016). Learning with the guided inquiry model provides opportunities for students to learn biology by constructing their own knowledge through direct information with the object being studied (Andiasari, 2015).

Analytical thinking skills between conventional classes and guided inquiry classes can be different because in the learning process using the guided inquiry model the teacher does not just let go of the activities carried out by students, so students who think slowly are still able to follow ongoing activities (Purwanto, 2012). The direct interaction of students with the object being studied causes the knowledge and understanding gained by students to be more meaningful than being transferred directly from the teacher to the students. The meaningfulness of learning resulting from the activity of linking the subject matter discussed with events that are close to the daily lives of students. This can improve analytical thinking skills both in the process and test results. This is in line with the results of research by (Almuntasheri, 2016) which showed that students who used the guided inquiry model showed a significant increase in both conceptual understanding and level of concept understanding compared to students who did not use the guided inquiry model.

\section{Conclusion}

The results of the research that have been carried out show that the $t$ test results obtained a sig value (2tailed) of 0.000 . The probability value is less than 0.05 so it can be concluded that there are differences in analytical thinking skills in guided inquiry class and conventional class. The test results with the gain score obtained a value of 0.71 in the high category. So that the learning process with the guided inquiry model can improve students analytical thinking skills on biodiversity material in class X SMA.

\section{Acknowledgements}

Thankyou to the leadership and teaching at SMA Negeri 1 Kalasan and SMA Negeri 1 Prambanan, who have provided service facilities during research.

\section{References}

Agustina, L. (2016). Upaya meningkatkan kemampuan pemahaman konsep dan pemecahan masalah matematika siswa SMP Negeri 4 Sipirok kelas VII melalui pendekatan matematika realistik (PMR). Jurnal Eksakta, 1(1), 1-7. doi: http://dx.doi.org/10.31604/eksakta.v1i1.\%25p

Almuntasheri, S., Gillies, R. M., \& Wright, T. (2016). The effectiveness of a guided inquiry based, teachers professional development programme on saudi students understanding of density. Science Education International, 17(1), 16-39. Retrieved from: https://www.researchgate.net/3329

Anderson, L. W., \& Krathwohl, D. R. (2010). Kerangka landasan untuk pembelajaran, pengajaran dan asesmen. Yogyakarta: Pustaka Pelajar.

Andiasari, L. (2015). Penggunaan model inquiry dengan metode eksperimen dalam pembelajaran IPA di SMPN 10 Probolinggo. Jurnal Kebijakan dan Pengembangan Pendidikan, 3(1), 15-20. doi: https://doi.org/10.22219/jkpp.v3i1.2186 
Annisa, N., Sri, R., \& Umi, F. (2016). Peningkatan kemampuan berpikir analitis siswa melalui penerapan model pembelajaran inkuiri terbimbing. Journal of Biology Education, 5(2), 163170. doi: https:// doi.org/10.15294/jbe.v5i2.7153

Arjani, L.M., Wayan, S., \& Putri, S. (2020). Implementasi Kurikulum 2013 dan faktor-faktor yang memengaruhi pada pembelajaran IPA kelas VII di SMPNegeri 4 Kubutambahan tahun ajaran 2018/2019. Jurnal Pendidikan dan Pembelajaran Sains Indonesia, 3(1), 21-30. doi: http://dx.doi.org/10.23887/jppsi.v3i1.24619

Astriani, D., Herawati, S., Hadi, S., \& Betty, L. (2017). Profil keterampilan berpikir analitis mahasiswa calon guru IPA dalam perkuliahan biologi umum. Jurnal Penelitian Pendidikan IPA, 2(2), 6670.

doi:

http://dx.doi.org/10.26740/jppipa.v2n2.p66-70

Cahyono, B. (2017). Analisis keterampilan berpikir kritis dalam memecahkan masalah ditinjau perbedaan gender. Aksioma, 8(1), 50-64. doi: https://doi.org/10.26877/aks.v8i1.1510

Desti, B., Tritiyatma, H., \& Yusmaniar. (2020). Pengembangan kemampuan berpikir analitis peserta didik melalui model pembelajaran prepare, do, review pada materi indikator asam basa. Jurnal Riset Pendidikan Kimia, 10(2), 70-78. doi: https:// doi.org/10.21009/JRPK.102.02

Dettmer, Peggy. (2006). New blooms in established fields: four domains of learning and doing. ProQuest Education Journals, 28(2), 70-78. doi: https://doi.org/10.1080/02783190609554341

Effendi, R. (2017). Konsep revisi taksonomi bloom dan implementasinya pada pelajaran matematika SMP. Jurnal Ilmiah Pendidikan Matematika. 2(1): 7278.

doi:

https:// doi.org/10.26877/jipmat.v2i1.1483

Fadly, W. (2021). Profile of students analytical thinking skills in learning style for completing substance pressure problems. Jambura Physics Journal, 3(1), 1-15. doi: https:// doi.org/10.34312/jpj.v3i1.9792

Fitriani., W. F., \& Ulinnuha, N. F. (2021). Analisis keterampilan berpikir analitis siswa pada tema pewarisan sifat. Jurnal Tadris IPA Indonesia, 1(1), 55-67. Retrieved from: https://ejournal.iainponorogo.ac.id/index.php/j tii/article/view/64

Hake, R. R. (1999). Analyzing change/gain score. Indiana: Indiana University.

Heong Yee Mee, Widad., Jailani., \& Tee Tze Kiong (2011). The level of marzano higher order thinking skills among technical education students. International Journal of Social Science $\mathcal{E}$ Humanity. $\quad 1(2): \quad 121-125 . \quad$ doi: https://doi.org/10.7763/IJSSH.2011.V1.20
Ikhsan, N. K., \& Supian, H. (2018). Implementasi dan pengembangan kurikulum 2013. Jurnal Edukasi, 6(1), 193-202. doi: http://dx.doi.org/10.25157/je.v6i1.1682

Johnson, E. B. (2014). Contextual teaching and learning: menjadikan kegiatan belajar mengajar mengasyikkan dan bermakna (2nd edition ed). Bandung: Kaifa.

Kurniati, R., Harimukti., \& N.A. Jamil. (2016). Kemampuan berpikir tingkat tinggi siswa SMP di Kabupaten Jember dalam menyelesaikan soal berstandar PISA. Jurnal Penelitian dan Evaluasi Pendidikan, 20(2), 142-155. Retrieved from: 10.21831/pep.v20i2.8058

Maryani, M., \& Eva, N. (2016). Critical and analytical thinking skill in ecology learning: A correlational study. Jurnal Pendidikan Biologi Indonesia, 7(1), 6370. doi: https://doi.org/10.22219/jpbi.v7i1.13926

Mattew, M. B., Kenneth, I. O. (2013). A study on the effects of guided inquiry teaching method on students achievement in logic. The International Research Journal, 2(1): 133-140. Retrieved from: http://iresearcher.org

Mulyasa, E. (2017). Guru dalam implementasi kurikulum 2013. Bandung: PT Remaja Rosdakarya.

Murizal, A. Y., \& Yerizon. (2012). Pemahaman konsep matematis dan model pembelajaran quantum teaching. Jurnal Pendidikan Matematika, 1(1), 19$23 . \quad$ Retrieved from: https://www.academia.edu/22882439

Mustika, O. (2016). Pengaruh pendekatan saintifik berbasis discovery learning (DL) dan problem based learning (PBL) terhadap hasil belajar ditinjau dari komunikasi matematika. Biolmi, 1(2), 22-29. Retrieved from: http:/ / eprints.ums.ac.id

Nilah \& L, R. (2020). Analisis kemampuan berpikir analitis dan evaluasi dalam pembelajaran fisika pada topik usaha dan energi. Prosiding Seminar Nasional Fisika (E-Journal), Universitas Negeri Jakarta, 7582, Desember 2020. Jakarta: Program Studi Fisika dan Pendidikan Fisika, Fakultas MIPA. doi: https://doi.org/10.21009/03.SNF2020.02.PF.12

Nugraha, A. J., Hardi, S., \& Endang, S. (2017). Analisis kemampuan berpikir kritis ditinjau dari keterampilan proses sains dan motivasi belajar melalui model PBL. Journal of Primary Education, 6(1), 35-43. doi: https://doi.org/10.15294/JPE.V6I1.14511

Nurgiyantoro, B., Gunawan., \& Marzuki. (2015). Statistik terapan untuk penelitian ilmu sosial: teori dan praktik dengan IBM SPSS statistic 21. Yogyakarta: Gadjah Mada University Press.

Patandean, A.J. (2014). Penilaian portofolio dalam pembelajaran fisika berbasis inquiri terbimbing. 
Jurnal Sains dan Pendidikan Fisika, 10(3): 255-262. doi: https://doi.org/10.35580/jspf.v10i3.962

Purwanto, A. (2012). Kemampuan berpikir logis siswa SMA Negeri 8 kota Bengkulu dengan menerapkan model inkuiri terbimbing dalam pembelajaran fisika. Jurnal Exacta, 10(2): 133-135. Retrieved http://repository.unib.ac.id/id/eprint/518

Rofiah, E., Nonoh, S. A., \& Elvin, Y. E. (2013). Penyusunan tes kemampuan berpikir tingkat tinggi fisika pada siswa SMP. Jurnal Pendidikan Fisika, 1(2), 17-22. Retrieved from: https://jurnal.fkip.uns.ac.id/index.php/pfisika/ article/view/2797

Rosana, L. N. (2014). Pengaruh metode pembelajaran dan kemampuan berpikir kritis terhadap hasil belajar sejarah siswa. Jurnal Pendidikan Sejarah, 3(1), 34-44. doi: https:// doi.org/10.21009/JPS.031.04

Spaska, A. (2021). Enhancing analitycal thingking in tertiary students using debates. European Journal of Educational Research, 10(2), 879-889. doi: https://doi.org/10.12973/eu-jer.10.2.879

Sukma., Komariyah, L., \& Syam, M. (2016). Pengaruh model pembelajaran inkuiri terbimbing (Guided Inquiry) dan motivasi terhadap hasil belajar fisika siswa. Jurnal Ilmu Pendidikan MIPA dan MIPA, 18(1): 2502-2768. Retrieved from: https://jurnal.unej.ac.id/index.php/STF/article $\angle$ view $/ 3185$

Sukriyanto., Nanik, Y., \& Umar, HM, S. (2014). Penerapan metode inquiry dalam meningkatkan aktivitas dan hasil belajar siswa mata pelajaran IPS pokok bahasan akibat perilaku manusia terhadap lingkungan di kelas IV SDN Barjasa Situbondo tahun 2012/2013. Unej Jurnal Pendidikan, 1(1), 32-34. Retrieved from: https://jurnal.unej.ac.id

Sulistiawati. (2014). Analisis kesulitan belajar kemampuan penalaran matematis siswa SMP pada materi luas permukaan dan volume limas. Proceeding Seminar Nasional Pendidikan dan TIK STKIP Surya, Universitas STKIP Surya, 205-225, Februari 2014. Tangerang: Program Studi Pendidikan Matematika.

Tse, N. C. J. (2013). Identify different concepts and definitions of 'Curriculum' and show how they can be related to what you do as a teacher in the classroom. The Hong Kong Institute of Education all Rights Reserved. Retrieved from: https://www.eduhk.hkstudentPDF

Ural, E. (2016). The effect of guided-inquiry labolatory experiments on science education students chemistry labolatory attitudes, anxiety, and achievement. Journal of Education and Training
Studies, $\quad 4(4), \quad 217-227 . \quad$ doi: http://doi.org/10.11114/jets.v4i4.1395

Utari, V., Fauzan, A., \& Rosha, M. (2012). Peningkatan kemampuan pemahaman konsep melalui pendekatan PMR dalam pokok bahasan prisma dan limas. Jurnal Pendidikan Matematika Part 3. 1(1): 33-38. Retrieved from: https://www.ejurnal.com/2015/03

Winarti. (2015). Profil kemampuan berpikir analisis dan evaluasi mahasiswa dalam mengerjakan soal konsep kalor. Jurnal Inovasi dan Pembelajaran Fisika, 2(1), 19-24. doi: https://doi.org/10.36706/jipf.v2i1.2350

Yulina, I. K., Permanasari, A., Hernani, H., \& Setiawan, W. (2019). Analytical thingking skill profile and perception of pre-service chemistry teachers in analitycal chemistry learning. Journal Physics Conference Series, 1157(4), 1-7. doi:https://doi.org/10.1088/17426597/1157/4/042046

Yustian, S., Nur, W., \& Yuni, P. (2015). Peningkatan kemampuan berpikir kritis dengan pembelajaran berbasis scientific approach siswa kelas $X$ sma panjura malang. Jurnal Pendidikan Biologi Indonesia, 1(2), 240-254. doi: https://doi.org/10.22219/jpbi.v1i2.3335

Yuwono, G. R., Widha, S., \& Nonoh, S. A. (2020). Pengaruh kemampuan berpikir analitis pada pembelajaran berbasis masalah (PBL) terhadap hasil belajar ranah pengetahuan. Edusains, 12(1), 10-112. doi: https://doi.org/10.15408/es.v12i1.11659 